\title{
Isolation, Molecular and Electron Microscopic Detection of PPR Virus from Suspected Outbreaks of PPR in Goats of North - Eastern Karnataka, India
}

\author{
K.C. Mallinath ${ }^{1 *}$, A. Basavaraj ${ }^{1}$, Amitha R. Gomes ${ }^{2}$, B.H. Jagadish ${ }^{3}$, \\ M. Shivaraj', R. Bhoyar ${ }^{4}$, S.M. Byregowda ${ }^{2}$, N.A. Patil ${ }^{4}$, \\ C. Jagannathrao ${ }^{4}$, P. Ubhale $^{1}$ and Phani Kashyap ${ }^{3}$ \\ ${ }^{1}$ Department of Veterinary Microbiology, Veterinary College, Bidar-585401, \\ Karnataka, India \\ ${ }^{2}$ IAH \&VB-Bengaluru, Karnataka, India \\ ${ }^{3}$ ICAR-NIVEDI- Bengaluru, Karnataka, India \\ ${ }^{4}$ Veterinary College, Bidar, Karnataka, India \\ *Corresponding author
}

\section{A B S T R A C T}

Region wise monitoring of the PPR virus by active surveillance is essential as it aids in strategic planning of measures of disease control and prevention. The North Eastern Karnataka with sizable sheep and goat population experiences the outbreaks of PPR but

\section{Keywords}

PPR, TEM,

Morbilli-virus, N, F gene etc.

Article Info

Accepted:

22 April 2018

Available Online:

10 May 2018 the attempts to isolate and characterize the prevailing PPR virus is limited. Hence, the present research work was carried out with the objective of isolation and characterization of PPR virus isolates circulating in North Eastern Karnataka by microscopic (TEM) and molecular (RT-PCR) methods. A total of 15 suspected PPR outbreaks were attended and different types of clinical samples like nasal, oral, ocular, rectal swabs and blood from ailing kids and goats were collected. The samples were initially screened for the presence of PPR virus by observing the infected Vero-cells for development of characteristic CPE. The isolates showing CPE were further confirmed for the virus by RT-PCR using $\mathrm{N}$ and $\mathrm{F}$ genes of PPR virus. The PCR confirmed isolates were subjected to transmission electron microscopy (TEM). A total of six PPR isolates were obtained representing five districts of North Eastern Karnataka which were confirmed by RT-PCR. The TEM images showed pleomorphic virion particles with varying sizes indicative of Morbilli-virus. These findings provide the first documentation of PPR presence by microscopic and molecular characterization in the region.

\section{Introduction}

Peste des Petits Ruminants (PPR) is an economically important disease of sheep and goats. World Organization for Animal Health (OIE-previous name) identified as notifiable infectious disease of sheep and goat caused by virus belonging to Morbilli virus genus of family Paramyxoviridae (Gibbs et al., 1979) threatening food security and livelihood of small and marginal farmers across the world. Recent estimate of Food and Agriculture Organisation (FAO), indicated the economic loss due to PPR in India alone, is $\$ 2569.00$ 
million/year during 2012-2017. Realising the economic importance of the PPR disease and successful eradication of antigenically related Rinder pest virus from globe in June 2011, the International organizations (OIE and FAO) have set target of global elimination of the disease by 2030. Though disease is endemic in India, caused by single serotype involving lineage-IV (Asian), recent outbreaks of lineage (IV) PPR virus in Africa and European part of Turkey where outbreaks due to lineage I, II, III were common, had necessitated the continuous surveillance of the disease in an endemic region (Banyard et al., 2010). Hence continuous monitoring of the type of virus circulating in the region by active surveillance is necessary in understanding the epidemiology of disease and planning the measures of disease eradication. Considering the above facts and figures, present study reports about isolation, molecular and electron microscopic detection of PPR virus from suspected outbreaks of the disease recorded in goats of North eastern region of Karnataka comprising five districts.

\section{Materials and Methods}

\section{Sample collection}

Different clinical samples like nasal, oral, ocular, rectal swabs and blood in viral transport medium (VTM, Hi-media) from ailing kids and adult goats were collected from 15 different outbreaks recorded in North eastern region of Karnataka during the period from Jan-2017 to Dec-2017. Using the clinical score card the clinical signs of the disease were classified in to mild, moderate and severe form (Balamurugan et al., 2014).

A total of 85 nasal swabs, 85 ocular swabs, 85 oral swabs, 50 rectal swabs and 78 anticoagulated blood samples were collected aseptically in VTM and brought to laboratory in ice packs.

\section{Virus isolation}

Swab samples collected in VTM were initially freeze thawed thrice and used directly for isolation. From the whole blood, buffy coat is extracted and eluted in 1X PBS and used as inoculum for infection (OIE manual). Swabs from same place and species of outbreaks were pooled and syringe filtered using $0.45 \mu$ pore sized membrane filter (Gomes et al., 2016). One to one and half $\mathrm{ml}$ of filtrate was used as inoculum to infect the monolayer (80\% confluency) of Vero cells (African green monkey kidney cells at passage 140-160) grown in $\mathrm{T}-25 \mathrm{~cm}^{2}$ culture flask by preadsorption method (Nanda et al., 1996) with minor modifications. Inoculated cells were incubated at $37^{\circ} \mathrm{C}$ for one hour with intermittent shaking to allow adsorption of virus. Decant the virus inoculum followed by washing of infected cells with Minimum Essential Medium (serum free DMEM) and then added with maintenance medium (DMEM with 2\% serum) for further incubation at $37^{\circ} \mathrm{C}$ for 6-8 days with change of maintenance medium on alternate days. The cells were monitored daily under inverted microscope for cytopathic effects due to viral replication. The samples were processed up to $6^{\text {th }}$ passage. The specificity of the isolated virus was determined by RT-PCR. Total RNA isolated from cell culture-adapted isolates was subjected to reverse transcription to synthesize complementary DNA followed by its PCR amplification of $\mathrm{N}$ and $\mathrm{F}$ gene as described below.

\section{Reverse transcription polymerase chain reaction (RT-PCR)}

It was performed as per the protocol given in OIE Manual of Diagnostic Tests and Vaccines for Terrestrial Animals 2017. The total RNA was extracted from clinical materials and Vero-cell adopted isolates using RNA easy kit (RNeasy®Minikit Qiagen Inc, Valencia, CA, 
USA). RT-PCR was performed using Thermo Scientific Revert Aid First Strand cDNA Synthesis Kit for c-DNA synthesis followed by PCR amplification using multiple sets of PPR virus genes ( $\mathrm{N}$ and $\mathrm{F}$ ) specific primers (Table 1), master mix reagents (Qiagen Inc, Valencia, CA, USA) and PCR conditions (Table 2).

\section{Detection of virus by Transmission Electron Microscopy (TEM)}

The concentrated and purified virus pellet of each of the isolate was reconstituted in PBS and $3 \mu 1$ of each one of them were pipetted out on a paraffin wax strip fixed on a glass slide. The samples were then deposited onto glowdischarger carbon coated copper grids (200 mesh Sigma Aldrich, India) by floating it on the respective samples present on wax strip and incubating it for 1 minute at room temperature. Excess sample was blotted using filter paper after incubation and the grid was washed twice with Milli-Q water. Samples were negatively stained with $2 \%$ uranyl acetate for 1-2 minutes (Brenner and Horne, 1959), excess stain was blotted away with filter paper and the grids were allowed to dry. The grids were finally examined on Transmission Electron Microscope HT7700 series at Indian Institute of Horticulture Research (IIHR), Bengaluru operated at $80 \mathrm{KV}$ and images were captured at different magnifications $(5 \mathrm{k}, 10 \mathrm{k}, 15 \mathrm{k}, 20 \mathrm{k}, 25 \mathrm{k}$ and 30k)

\section{Results and Discussion}

\section{Epidemiological observations}

A total of 15 outbreaks were attended in the region during the period under study. The clinical signs like elevated temperature, mucous/muco-purulent nasal and ocular discharge, congested nasal and ocular mucous membrane, crusts around nostrils, respiratory distress, severe mucosal erosion, salivation, ulcers on tongue, watery diarrhoea with soiled hind quarters were observed in the outbreaks and clinical cases attended. Based on the clinical score card the disease was classified into mild, moderate and severe form (Balamurugan et al., 2014). The mild form of disease was characterized by serous nasal and ocular discharge, ulcers in the mouth, respiratory distress (Fig.1A-C) and mild diarrhea, while moderate form showed clinical signs like moderate pyrexia, mucous nasal and ocular discharge, ulcers and bran like depots in the mouth, and watery diarrhoea (Fig.2DF). The severe form showed signs characterized by hyperaemia, mucopurulant nasal and ocular discharge, sloughing of oral mucosa, formation of crust in and around nostril and eyes, severe watery diarrhoea with soiled hind quarters (Fig.3G-I). Severe form of the disease was recorded more in the kids than adults which experienced mild to moderate forms of the disease.

\section{Virus isolation}

A total of six isolates were obtained from the samples subjected for isolation among which five isolates were recovered from nasal swabs, one from ocular and none from blood and rectal swabs. The isolates obtained showed two patterns of characteristic cytopathic effects like rounding and detachment from surface, later on aggregation of cells followed by fusion mass and in other type, CPE was characterized by cells of increased refractivity, rounding and ballooning of cells, clumping into grape like clusters and appearance of fine spindle cells with elongated processes [Fig.4 (A-D)] (Hamby and Dardiri, 1976).

The recovery of virus isolates was observed at different passage levels in which one isolate was recovered on $3^{\text {rd }}$ day of post infection (dpi) in the first passage, two isolates on $2^{\text {nd }}$ and $4^{\text {th }}$ dpi in $2^{\text {nd }}$ passage, two isolates on $3^{\text {rd }}$ 
and $5^{\text {th }}$ dpi in $3^{\text {rd }}$ passage and one isolate on $2^{\text {nd }} \mathrm{dpi}$ in $5^{\text {th }}$ passage indicating specifically the load of the initial virus in the clinical samples.

The analysis of the isolation results indicates that the relative recovery of virus using nasal swabs and ocular swab was better than faecal and blood samples suggesting to consider nasal swab and ocular swab be better choice of sample for disease diagnosis in ailing animals by isolation (Forsyth and Barrett, 1995; Diop et al., 2005; Harshad et al., 2014). The failure of isolation from blood and rectal swab could be attributed to presence of certain inhibitory or cytotoxic factors present in blood or rectum and labile character of the virus, initial concentration of virus in the clinical material, sampling and delivery time of the sample to laboratory (Harshad et al., 2014). Though isolation of virus is laborious and time consuming, yet is considered to be gold standard test for confirming any aetiologcal agent in an outbreak which is a mandatory method for declaring disease free status in any region.

\section{RT-PCR Detection}

RNA viruses are known to be subjected to high nucleotide substitution error frequencies (Steinhauer et al., 1989). Therefore for routine detection of the virus from different origins, there is a risk of a false negative result if the PCR is carried out with two primers that were designed according to the gene sequences of only one virus strain which could be minimized if two sets of primers used to amplify two different fragments or if a set of primers is synthesized after taking into consideration of the sequences from several strains of different origins (Couacy-Hymann et al., 2002; Kerur et al., 2008 and Ularamu et al., 2012).

Hence all the isolates obtained during the study were tested by using four different sets of primer targeting different regions of genes from different strains which yielded expected amplicon size of $351 \mathrm{bp}, 463 \mathrm{bp}, 447 \mathrm{bp}$ and $371 \mathrm{bp}$ with primer sets of NP3 and NP4, N1 and N2, F1b and F2d and F1 and F2 respectively confirming the PPR virus (Fig. 5, 6, 7 and 8).

In order to confirm further identity of the virus the $\mathrm{N}$ gene specific 351 bp PCR product was gel purified and submitted for direct sequencing (EUROFFINS Bengaluru).

The sequences when searched for its similarity using NCBI BLAST, they were found to be PPR virus.

\section{TEM Detection}

Negative staining of RT-PCR confirmed isolates, when observed under TEM showed pleomorphic virion particles with varying sizes characteristic of Morbilli-virus (Losos 1989).

The detailed examination of the isolates by TEM under different magnification revealed the presence of pleomorphic virions mostly circular and elliptical in shape with diameter of intact particles ranging from 100 to $250 \mathrm{~nm}$ approximately (Fig. 9A, B, C, D) (Zahur et al., 2009; Sumit et al., 2013).

Review of literature indicate that work related to detection of virus by TEM using negative staining is scanty in India and hence present study could be a first report from state of Karnataka and one among few reports reported across the country till date.

Though immunologic and molecular diagnostic tests have high specificity in detecting an etiological agent than Electron microscopy, sometime these assays may fail to identify agents and hence sensitivity may equal that of Electron microscopy (Hammond et al., 1984; Jiang et al., 1996). 


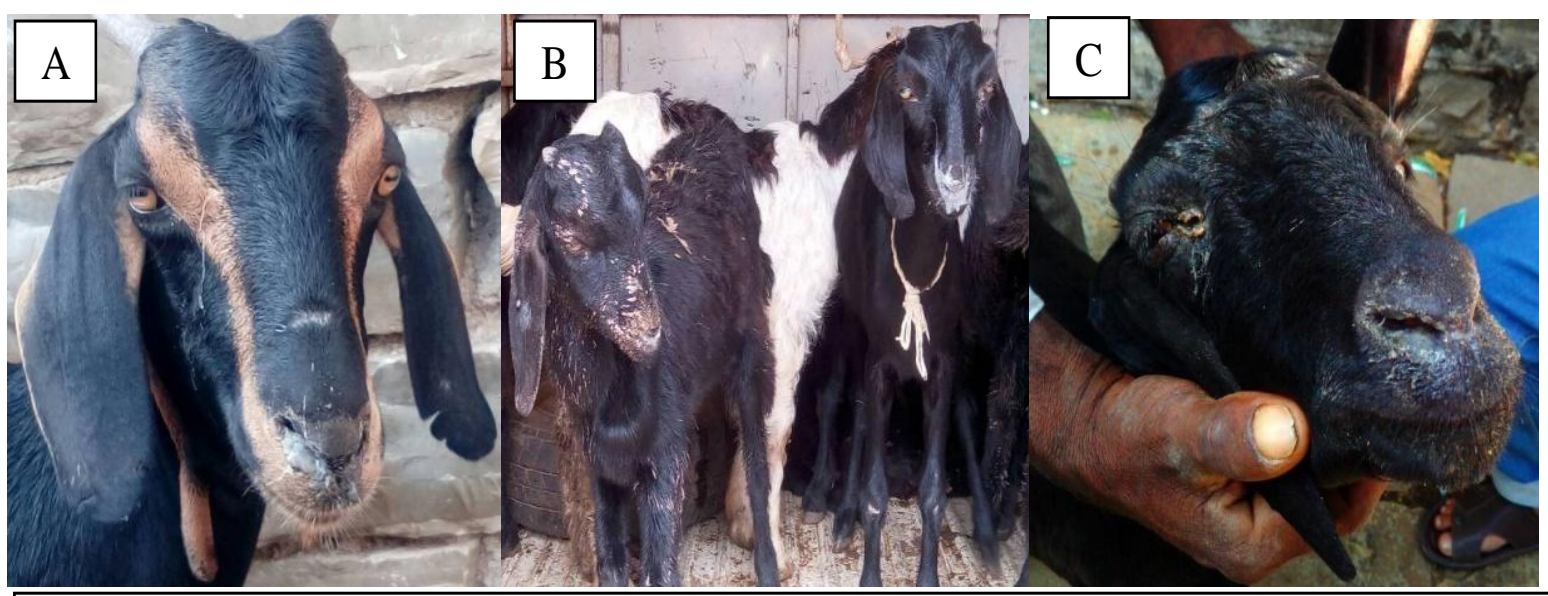

Fig 1.Mild form of PPR: Serous nasal ocular and oral discharge, respiratory distress $(\mathrm{A}, \mathrm{B}, \mathrm{C})$

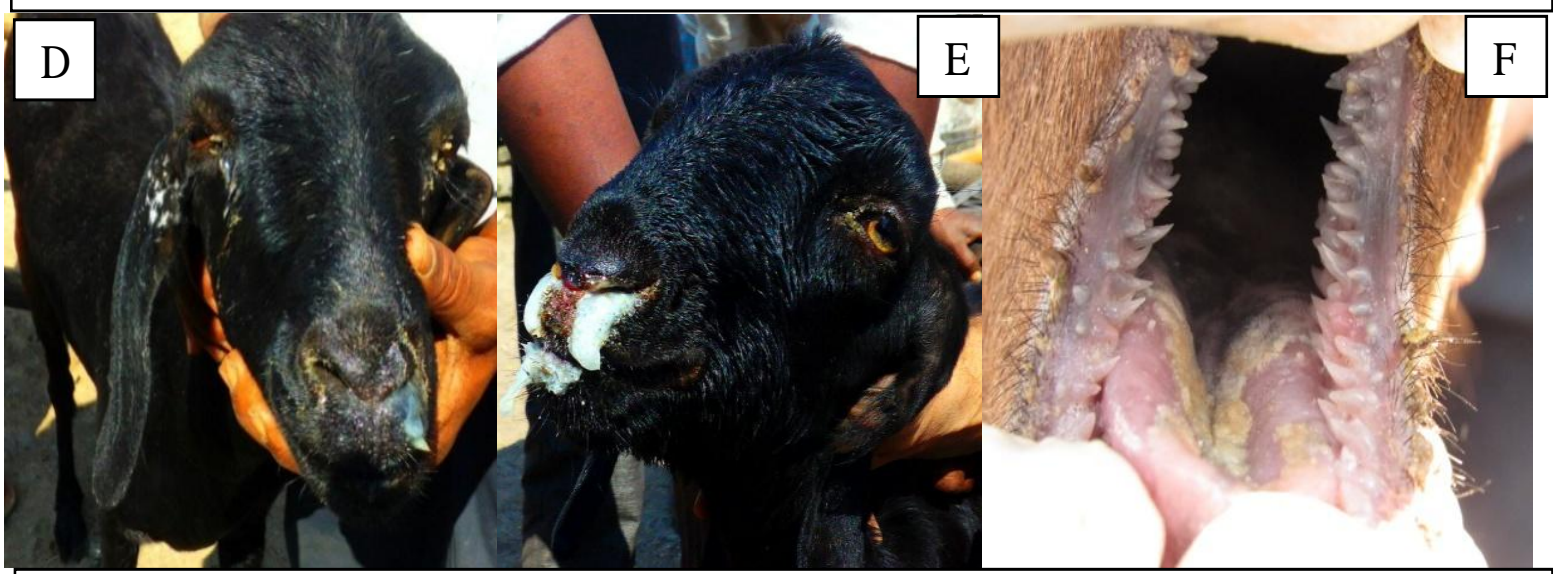

Fig 2.Moderate form of PPR:Mucous nasal and ocular discharge (D \& E), congestion of mucus membrane, ulcers and bran like depots in the mouth $(\mathrm{F})$

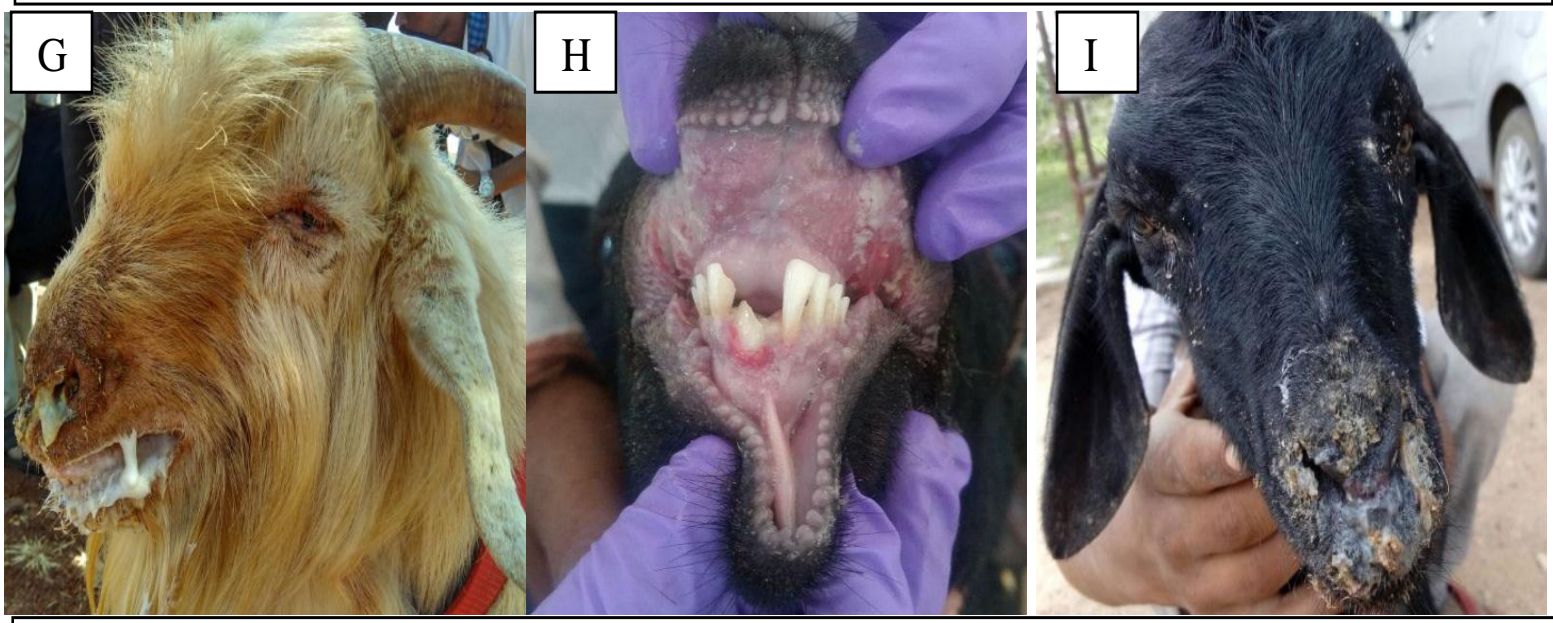

Fig.3. Severe form of PPR: Mucopurulant nasal and oral discharge (G), sloughing of oral mucosa $(\mathrm{H})$, formation of crust in and around nostril and eyes (I) 

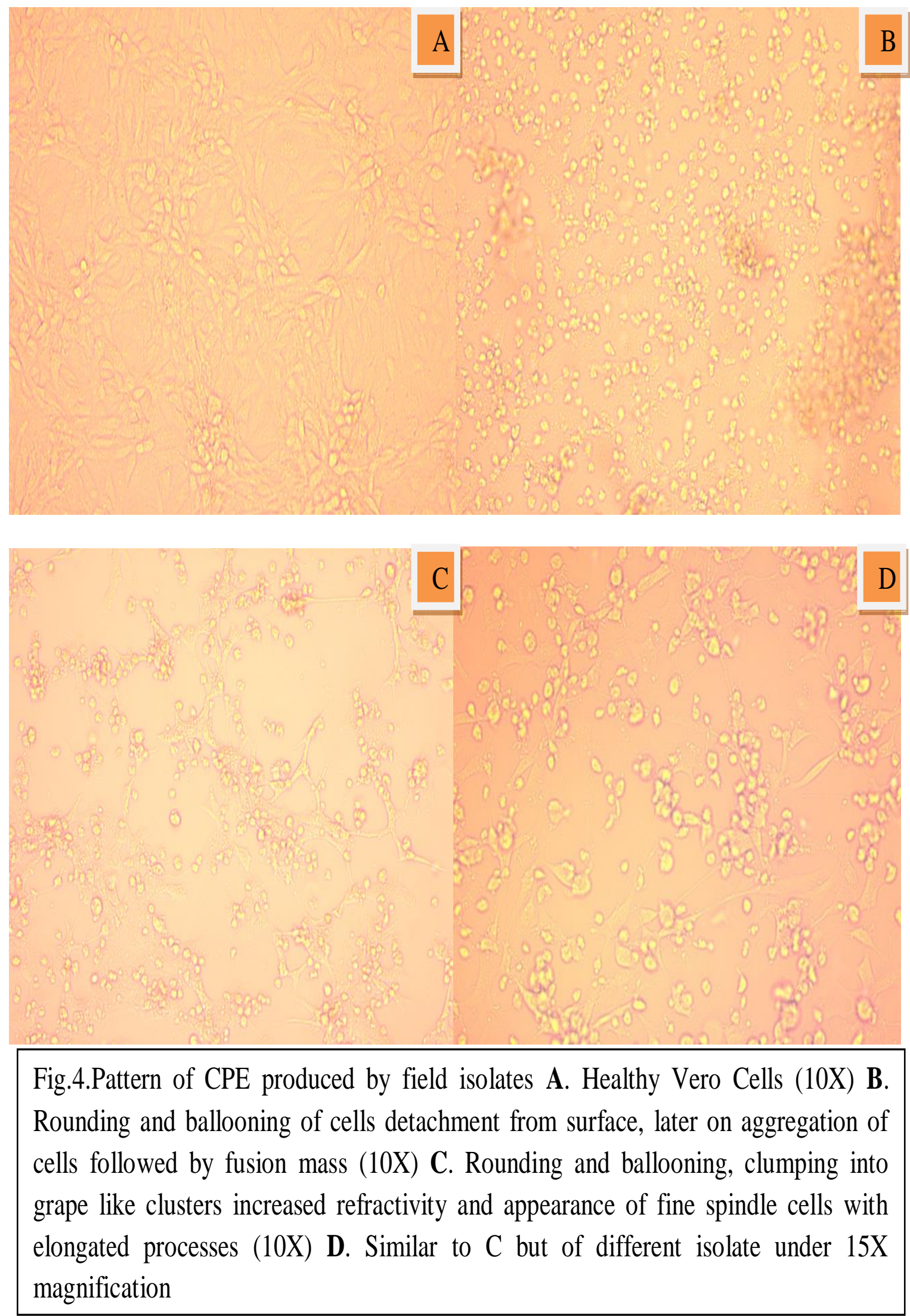


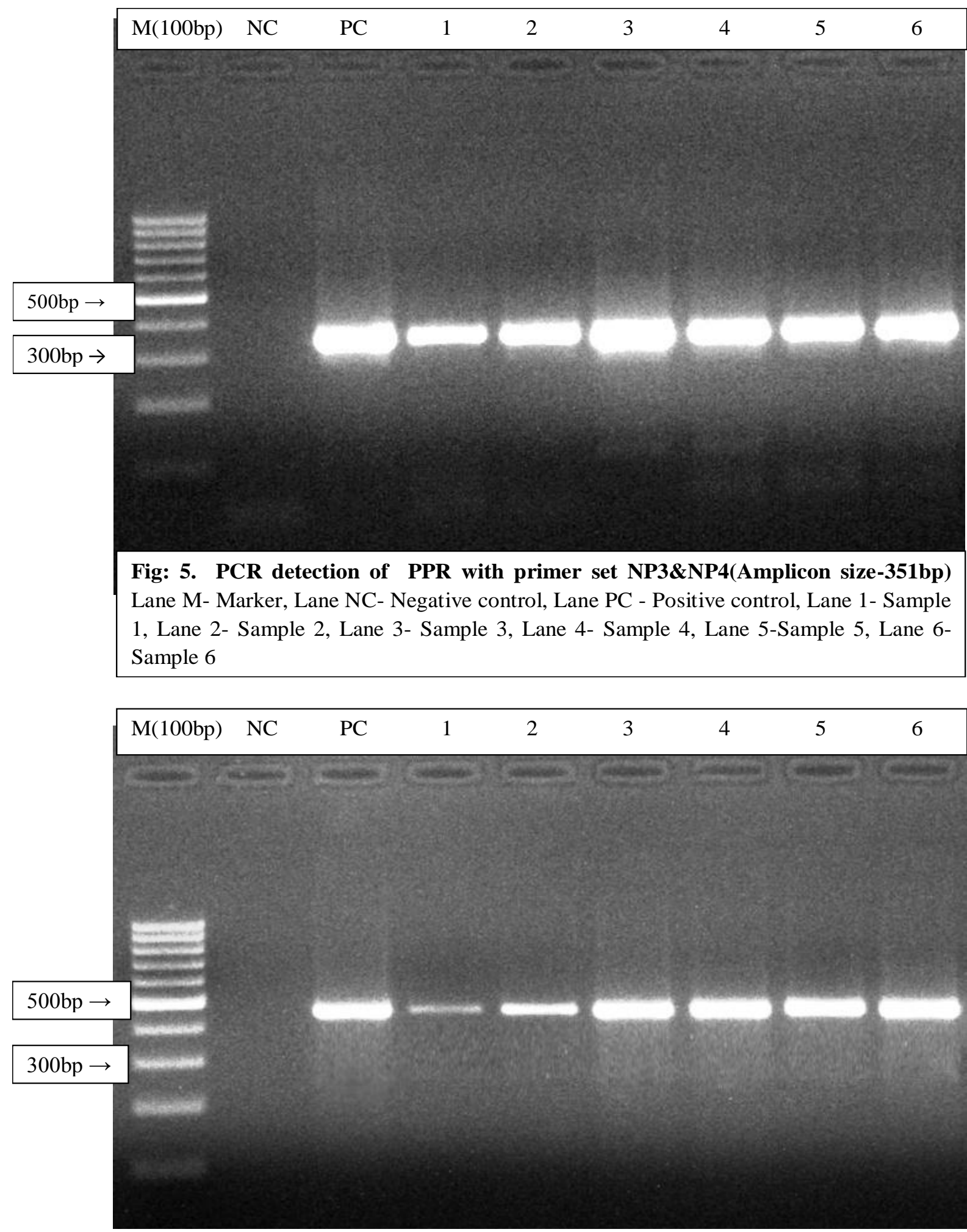

Fig: 6. PCR detection of PPR with primer set N1 \& N2 (Amplicon size-463bp) Lane M- Marker, Lane NC- Negative control, Lane PC - Positive control, Lane 1- Sample 1, Lane 2-Sample 2, Lane 3-Sample 3, Lane 4- Sample 4, Lane 5-Sample 5, Lane 6-Sample 6 

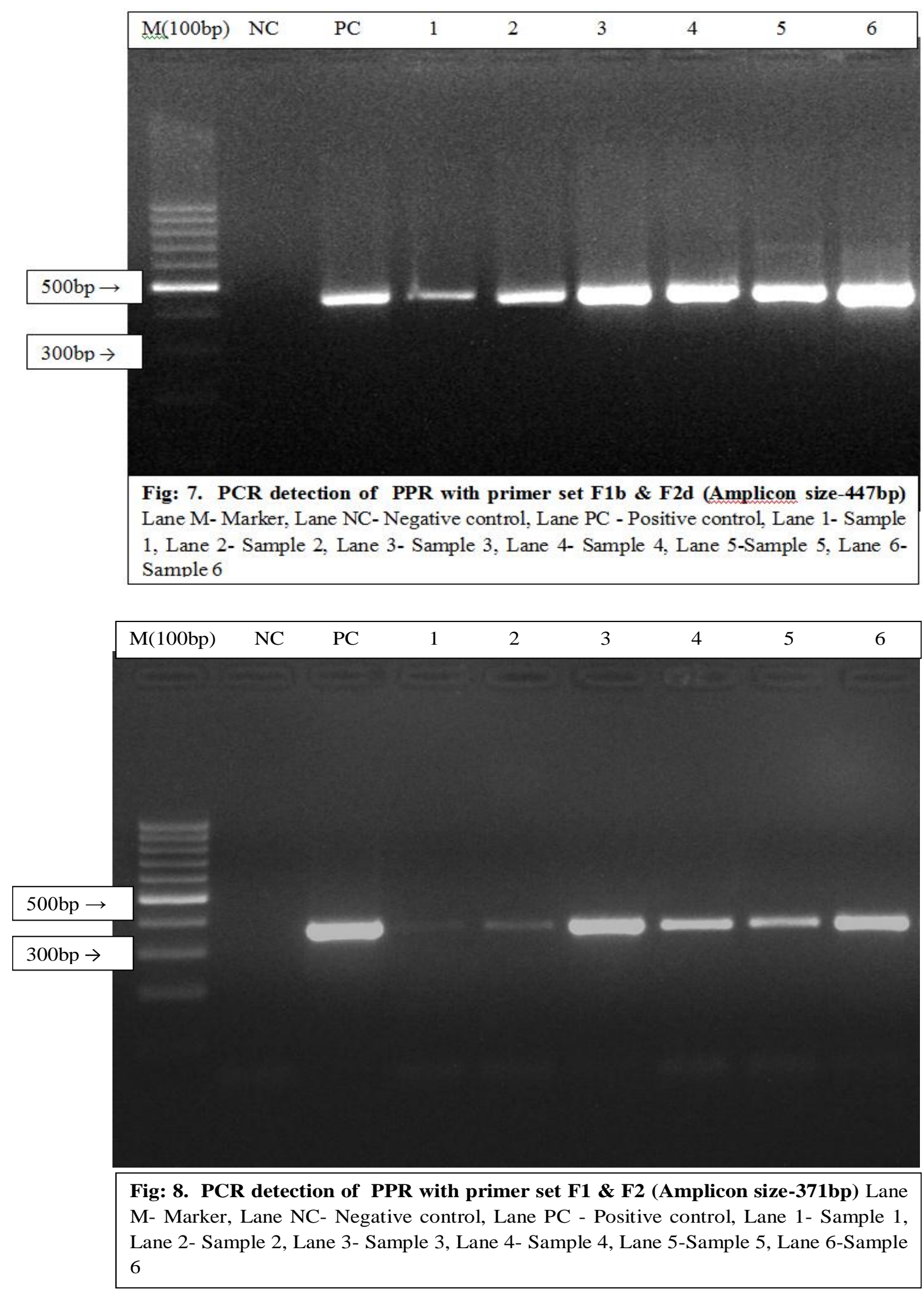

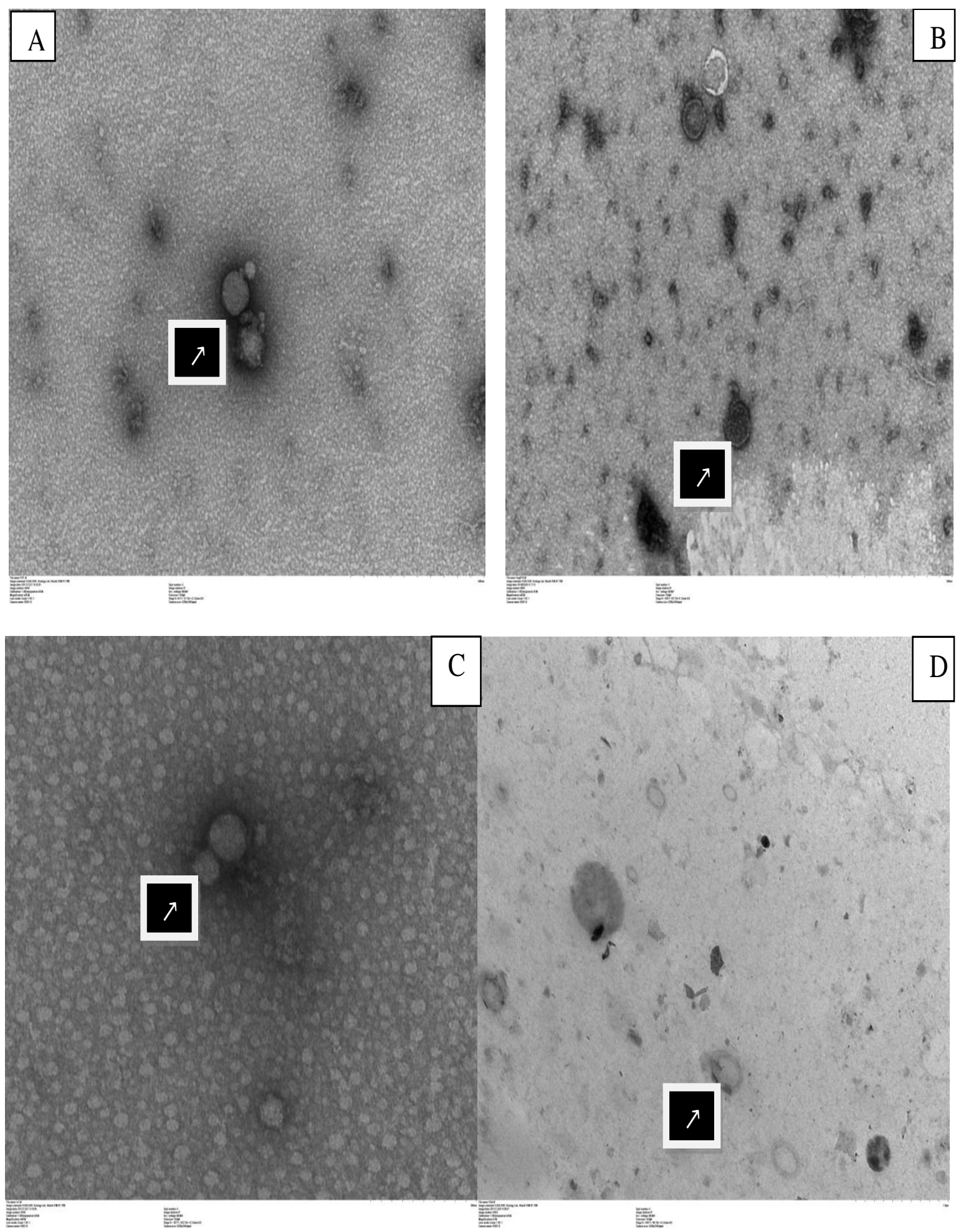

Fig.9 (A, B, C D) TEM of PPR virus: Negative staining showing pleomorphic virion particles under different magnification.(Magnifications:A-20K,B-20K C-10K and D-7K 
Table.1 PPR virus specific diagnostic primer sequences

\begin{tabular}{|c|c|c|c|c|}
\hline $\begin{array}{l}\text { SI } \\
\text { No }\end{array}$ & $\begin{array}{c}\text { Name of } \\
\text { the Primer }\end{array}$ & Primer sequences & $\begin{array}{c}\text { Amplicon } \\
\text { Size }\end{array}$ & Reference \\
\hline 1 & $\begin{array}{l}\text { NP3-F } \\
\text { NP4-R }\end{array}$ & $\begin{array}{l}\text { 5'-GTC-TCG-GAA-ATC-GCC-TCA-CAG-ACT-3' } \\
\text { 5'-CCT-CCT-CCT-GGT-CCT-CCA-GAA-TCT-3' }\end{array}$ & $351 \mathrm{bp}$ & $\begin{array}{l}\text { COUACY- } \\
\text { HAYMANN et } \\
\text { al., (2002) }\end{array}$ \\
\hline 2 & $\begin{array}{l}\mathrm{N} 1-\mathrm{F} \\
\mathrm{N} 2-\mathrm{R}\end{array}$ & $\begin{array}{l}\text { 5'-GAT-GGT-CAG-AAG-ATC-TGCA- 3' } \\
\text { 5'-CTT-GTC-GTT-GTA-GAC-CTGA 3' }\end{array}$ & $463 \mathrm{bp}$ & KERUR (2008) \\
\hline 3 & $\begin{array}{l}\text { F1b-F } \\
\text { F2d-R }\end{array}$ & $\begin{array}{l}\text { 5'-AGT-ACA-AAA-GAT-TGC-TGA-TCA-CAGT-3' } \\
\text { 5'-GGG-TCT-CGA-AGG-CTA-GGC-CCG-AATA-3' }\end{array}$ & $447 \mathrm{bp}$ & $\begin{array}{l}\text { DHAR et al., } \\
(2002)\end{array}$ \\
\hline 4 & $\begin{array}{l}\text { F1-F } \\
\text { F2-R }\end{array}$ & $\begin{array}{l}\text { 5'-ATC-ACA-GTG-TTA-AAG-CCT-GTA-GAGG -3' } \\
\text { 5'-GAG-ACT-GAG-TTT-GTG-ACC-TAC-AAGC- 3' }\end{array}$ & $371 \mathrm{bp}$ & $\begin{array}{l}\text { FORSYTH and } \\
\text { BARETT } \\
\text { (1995) }\end{array}$ \\
\hline
\end{tabular}

Table.2 PCR Conditions

\begin{tabular}{|c|c|c|c|c|c|}
\hline \multirow{2}{*}{$\begin{array}{l}\text { SI. } \\
\text { No. }\end{array}$} & \multirow{2}{*}{$\begin{array}{l}\text { Primer } \\
\text { Name }\end{array}$} & \multicolumn{3}{|c|}{ PCR conditions } & \multirow{2}{*}{ Remarks } \\
\hline & & Temp \& Time & Cycle & Step & \\
\hline \multirow[t]{6}{*}{1} & \multirow[t]{6}{*}{ NP3\&NP4 } & $50^{\circ} \mathrm{C}$ for $30 \mathrm{~min}$ & 1 & Reverse Transcription & \\
\hline & & $95^{\circ} \mathrm{C}$ for $15 \mathrm{~min}$ & 1 & Inactivates RT \& activates Polymerase & \\
\hline & & $94^{\circ} \mathrm{C}$ for $30 \mathrm{sec}$ & & & \\
\hline & & $60^{\circ} \mathrm{C}$ for $30 \mathrm{sec}$ & 40 & PCR Amplification of c-DNA & \\
\hline & & $72^{0} \mathrm{C}$ for $1 \mathrm{~min}$ & & & \\
\hline & & $72^{\circ} \mathrm{C}$ for $5 \mathrm{~min}$ & 1 & Final Extension & \\
\hline \multirow[t]{5}{*}{2} & \multirow[t]{5}{*}{$\mathrm{N} 1 \& \mathrm{~N} 2$} & $50^{\circ} \mathrm{C}$ for $30 \mathrm{~min}$ & 1 & Reverse Transcription & \\
\hline & & $94^{\circ} \mathrm{C}$ for $30 \mathrm{sec}$ & & & \\
\hline & & $50^{\circ} \mathrm{C}$ for $30 \mathrm{sec}$ & 35 & PCR Amplification of c-DNA & \\
\hline & & $72^{\circ} \mathrm{C}$ for $45 \mathrm{sec}$ & & & \\
\hline & & $72^{\circ} \mathrm{C}$ for $10 \mathrm{~min}$ & 1 & Final Extension & \\
\hline \multirow[t]{6}{*}{3} & \multirow[t]{5}{*}{ F1b \& F2d } & $50^{\circ} \mathrm{C}$ for $30 \mathrm{~min}$ & 1 & Reverse Transcription & \\
\hline & & $94^{0} \mathrm{C}$ for $2 \mathrm{~min}$ & 1 & Inactivates RT \& activates Polymerase & \\
\hline & & $94^{\circ} \mathrm{C}$ for $1 \mathrm{~min}$ & & & \\
\hline & & $55^{\circ} \mathrm{C}$ for $1 \mathrm{~min}$ & 35 & PCR Amplification of c-DNA & \\
\hline & & $72^{\circ} \mathrm{C}$ for $1 \mathrm{~min}$ & & & \\
\hline & & $72^{0} \mathrm{C}$ for $7 \mathrm{~min}$ & 1 & Final Extension & \\
\hline \multirow[t]{5}{*}{4} & \multirow[t]{5}{*}{$\mathrm{F} 1 \& \mathrm{~F} 2$} & $94^{0} \mathrm{C}$ for $3 \mathrm{~min}$ & 1 & Activates Polymerase & \multirow{5}{*}{$\begin{array}{l}\text { PCR } \\
\text { product of } \\
\text { F1b\&F2d is } \\
\text { used as } \\
\text { template }\end{array}$} \\
\hline & & $94^{0} \mathrm{C}$ for $1 \mathrm{~min}$ & & PCR Amplification of c-DNA & \\
\hline & & $55^{0} \mathrm{C}$ for $1 \mathrm{~min}$ & 34 & & \\
\hline & & $72^{\circ} \mathrm{C}$ for $1 \mathrm{~min}$ & & & \\
\hline & & $72^{\circ} \mathrm{C}$ for $10 \mathrm{~min}$ & 1 & Final Extension & \\
\hline
\end{tabular}


Change in the sequences of primer target region on a viral genome due to mutations may sometime decrease the sensitivity and effectiveness of primer set and thus the ability of nucleic acid amplifications tests like PCR. The use of such tests may not able to identify certain sub-viral components such as empty virions which may be seen late in an infection and which could be identified by Electron microscopy.

Hence practical level of sensitivity of molecular and immunological tests cannot always exceed that of Electron microscopy (Ando et al., 1995; Vinje et al., 2000; Green et al., 2002). The TEM results of our study had endorsed the confirmation of PPR virus by PCR. Hence TEM technique could also be used as a frontline diagnostic method in parallel with other diagnostic tests for diagnosis of viral infection if facility of TEM is available.

\section{Confirmation of outbreak}

Based on above results the aetiology of outbreaks were confirmed to be PPR virus indicating its circulation in the region in-spite of having a very good vaccine which many investigators have justified with introduction of new animals into flocks and movement of animals from one place to other for food, playing a key role in the transmission and maintenance of PPRV in the nature.

Global target of PPR eradication can only be achieved by prompt reporting of the outbreak, rapid and accurate diagnosis and implementation of prompt control measures. Monitoring the clinical prevalence of the virus in different geographical areas of the country with varying agro-climatic conditions may be helpful for establishing disease control strategies and helps to the know the actual infection rate (Balamurugan et al., 2012).

\section{Acknowledgment}

I sincerely thank Dean, Veterinary College Bidar, Director IAH\&VB and Director NIVEDI for their generous help provided in terms of research facilities, technical guidance and motivation in carrying out the present work. I cannot forget to extend my sincere thanks to the field veterinarians for their invaluable help provided in collection of samples, my thanks are due for senior and junior friends for moral support in carrying out present work.

\section{References}

Ando, T., Monroe, S.S., Gentsch, J.R., Jin, Q., Lewis, D.C. and Glass, R.I., 1995. Detection and differentiation of antigenically distinct small roundstructured viruses (Norwalk-like viruses) by reverse transcription-PCR and southern hybridization. J. Clin. Microbiol, 33: 64-71.

Balamurugan, V., Govindaraj, G., Nagalingam, M., Hemadri, D., and Gajendragad, M.R. 2014. Peste Des Petits Ruminants (PPR), Clinical score card for assessing the disease pattern during PPR outbreaks in the field. NIVEDI Tech. Bulletin., 31.

Balamurugan, V., Saravanan, P., Sen, A., Rajak, K.K., Venkateshan, G., Krishnamoorthy, G., Bhanuprakash, V., Singh, R.K. 2012.Prevalence of Peste des Petits Ruminants among sheep and goats in India. J. Vet. Sci., 13: 279-85.

Baynard, A.C., Parida, S., Batten, C., Oura, C., Kwiatek, O., Libeau, G. 2010.Global Distribution of Peste Des Petits Ruminants Virus and Prospects for Improved Diagnosis and Control. J.Gen.Virol., 91: 2885-2897.

Brenner, S. and Horne, R.W.1959. A negative staining method for high resolution electron microscopy of viruses. 
Biochimica et Biophysica Acta., 34: 103-110.

Couacy-Hymann, E., Roger, F., Hurard, C., Guillou, J. P., Libeau, G. and Diallo, A. 2002. Rapid and sensitive detection of peste des petits ruminants virus by a polymerase chain reaction assay. J. Virol. Methods, 100:17-25.

Dhar, P., Sreenivasa, B.P., Barrett, T., Corteyn, M., Singh, R.P. and Bandyopadhyay, S. K.2002. Recent epidemiology of Peste des petits ruminants virus (PPRV). Vet. Microbiol, 88: 153-159.

Diop, M., Sarr, J., and Libeau, G. 2005 Evaluation of novel diagnostic tools for Peste Des Petits Ruminants virus in naturally infected goats. Epidemiol. Infect, 133: 711-717

FAO, OIE, 2015. Global Strategy for the Control and Eradication of Peste Des Petits Ruminants. FAO, Rome. http://www.fao.org/3/a-i4460e.pdf. Accessed on 1/3/2016.

Felix, N. 2013. Current scenario and control initiatives for PPR at global, regional and country level according to the risk factors and socioeconomic impact. In Proceedings of the Second Regional Conference on Progressive Control of Peste Des Petits Ruminants in South Asia, Kathmandu, Nepal, 19-20 December 2013.

Forsyth, A and Barret T 1995b. Isolation and Identification of Peste Des Petits Ruminants virus. J.Vet.Med.Series B, 42: 61-69

Forsyth, M., and Barrett, T. 1995a. Detection and differentiation of rinderpest and peste despetits ruminants viruses in diagnostic and experimental samples by polymerase chain reaction using $\mathrm{P}$ and $\mathrm{F}$ gene-specific primers. Virus Res. 39: 151-163.

George, A. A. 2002. Comparative evaluation of different gene targets for PCR diagnosis of PPR. M. V. Sc. Thesis submitted to Indian Veterinary Research Institute, Deemed University, Izatnagar, Bareilly India.

Gibbs, E. P., Taylor, W.P., Lawmann, M.J. and Bryant, J. 1979. Classification of Peste Des Petits Ruminants Virus as the fourth member of the genus Morbillivirus. Intervirology. 11: 268274

Gomes, A.R., Byregowda, S.M., Veeregowda, B.M., Rathnamma, D., Chandranaik, B.M., Shivashankar, B.P., Mallinath, K.C., and Balamurugan, V. 2016. Epidemiological investigation of the Peste des Petits Ruminants outbreaks in Karnataka, India. Adv. Anim. Vet. Sci. 4(2s): 27-33

Green, K.Y., Belliot, G., Taylor, J.L., Valdesuso, J., Lew, J.F., Kapikian, A. Z. and Lin, F.Y. 2002. A predominant role for Norwalk-like viruses as agents of epidemic gastroenteritis in Maryland nursing homes for the elderly. J. Infect. Dis.185: 133-146.

Hamby, and Dardiri, A. H. 1976. Response of white tailed deer to infection with Peste des petits Ruminants. J.wildl.dis.12:516-522.

Hammond, G.W., Ahluwalia, G.S., Klisko, B. and Hazelton, P.R. 1984. Human rotavirus detection by counter immune electrophoresis versus enzyme immunoassay and electron microscopy after direct ultracentrifugation. J. Clin. Microbiol.19: 439-441.

Harshad, C.C., Hemendra singh, K., Kaushal, K.K., Arnab, S., Abidali, I.D., and Bharat Singh, C. 2014. Epidemiology and diagnosis of Peste des petits Ruminants in sheep and goats by Serological, Molecular and Isolation Methods in Gujarat, India. Advances in Animal and Veterinary Sciences. 2(4):192-198. 
Jiang, X., Turf, E., Hu, J., Barrett, E., Dai, X.M., Monroe, S., Humphrey, C., Pickering, L.K. and Matson, D.O. 1996. Outbreaks of gastroenteritis in elderly nursing homes and retirement facilities associated with human caliciviruses. J. Med. Virol.50: 335-341.

Kerur, N., Jhala, M.K. and Joshi, C.G., 2008. Genetic characterization of Indian Peste Des Petits Ruminants virus (PPRV) by sequencing and phylogenetic analysis of fusion and nucleoprotein gene segments. Res.Vet.Sci.85:176-183

Losos, G.J., 1989. Infectious Tropical diseases of domestic animals. Longmann Scientific Technical Canada 12:549-556

Nanda, Y. P., Chatterjee, A.K., Purohit, A., Diallo, K., Innui, A., Sharma, K.R Libeau, N., Thevasagayam, G.J., Bruning, A., Kitching, A., Anderson, P., T Barrett, J. and Taylor, T.W. P. 1996. Isolation of Peste des petits ruminants virus from Northern India. Vet Microbiol. 51: 207-2016

Steinhauer, D.A., De La Torre, J. C and Holland, J.J. 1989. High nucleotide substitution error frequencies in clonal pools of vesicular stomatitis virus. J. Virol. 63:2063-2071.

Sumit, M., Rajesh, A., Mahesh, K., Anand, M., Akhilesh, K., Nishe, P. and Raj, N. T. 2013. Electron microscopy based detection of PPR virus in goat and its confirmation by sandwich-ELISA and RT-PCR. Indian J.Vet Med. 33(2):9295

Ularamu, H.G., Owolodun, O.A., Woma, T.Y., Audu, B.J., Aaron. G.B., Chollum, S.C., and Shamaki, D., 2012. Molecular diagnosis of recent suspected outbreaks of Peste Des Petits Ruminants (PPR) in Yola, Adamawa state, Nigeria. African Journal of Biotechnology. 11(5): 1158-1162

Vinje, J., Deijl, H., Van der Heide, R., Lewis, D., Hedlund, K.O., Svensson, L. and Koopmans, M.P. 2000. Molecular detection and epidemiology of Sapporolike viruses. J. Clin. Microbiol.38: 5306.

Zahur, A.B., Ullah, A., Irshad, H., Farooq, M.S., Hussain. M. And Jahangir, M. 2009. Epidemiological investigations of a Peste-des petits ruminants (PPR) outbreak in afghan sheep in Pakistan. Pakistan Vet. J. 29(4): 174-178.

\section{How to cite this article:}

Mallinath, K.C., A. Basavaraj, Amitha R. Gomes, B.H. Jagadish, M. Shivaraj, R. Bhoyar, S.M. Byregowda, N.A. Patil, C. Jagannathrao, P. Ubhale and Phani Kashyap. 2018. Isolation, Molecular and Electron Microscopic Detection of PPR Virus from Suspected Outbreaks of PPR in Goats of North - Eastern Karnataka, India. Int.J.Curr.Microbiol.App.Sci. 7(05): 32063218. doi: https://doi.org/10.20546/ijcmas.2018.705.375 